\title{
Antitumor Effect of IL-2 and TRAIL Proteins Expressed by Recombinant Salmonella in Murine Bladder Cancer Cells
}

\author{
Bruna Dias de Lima Fragellia Luciana Camillo \\ Joice Margareth de Almeida Rodolpho ${ }^{a}$ Krissia Franco de Godoya \\ Cynthia Aparecida de Castro ${ }^{a}$ Patricia Brassolattia Adilson José da Silva ${ }^{b}$ \\ Ricardo Carneiro Borrac Fernanda de Freitas Anibal ${ }^{a}$ \\ aLaboratório de Inflamação e Doenças Infecciosas, Departamento de Morfologia e Patologia, \\ Universidade Federal de São Carlos, São Carlos, Brazil, 'Laboratório de Fábrica Celular, Departamento \\ de Engenharia Química, Universidade Federal de São Carlos, São Carlos, Brazil, 'Laboratório de \\ Imunologia Aplicada, Departamento de Genética e Evolução, Universidade Federal de São Carlos, São \\ Carlos, Brazil
}

\section{Key Words}

Salmonella $\bullet \mathrm{IL}-2 \cdot$ TRAIL $・$ Bladder Tumor $・$ MB49

\begin{abstract}
Background/Aims: Cancer is the second most deadly disease in the world. The bladder cancer is one of the most aggressive types and shows a continuous increase in the number of cases. The use of bacteria as live vectors to deliver molecules directly to the tumor is a promising tool and has been used as an adjuvant treatment against several types of cancer. The aim of this study was to investigate the antitumor effect of Interleukin 2 (IL-2), TNF-related apoptosisinducing ligand (TRAIL) and protein MIX against murine bladder cancer cells, lineage MB49. Methods: The attenuated Salmonella strain SL3261 was transformed by inserting the IL-2 and TRAIL genes. The effects of proteins on cell viability (MTT method), cell morphology (optical microscopy), cell recovery (clonogenic assay), cell membrane (lactate dehydrogenase release - LDH), on oxidative stress pathway (levels of nitric oxide, NO) and apoptosis (flow cytometry and high resolution epifluorescence images) were evaluated at intervals of 24 and 48 hours of action. Results: The results showed that there was a decrease in cell viability via damage to the cell membrane, alteration of cell morphology, non-recovery of cells, increase in the production of $\mathrm{NO}$ and incubate for of cells in the state of apoptosis in the two periods analyzed. Conclusion: The data presented suggest that IL-2, TRAIL and their MIX proteins in MB49 cells have cytotoxic potential and that this is associated with oxidative stress and apoptosis pathways. These results may contribute to the development of new therapeutic strategies for bladder cancer.




\section{Introduction}

Cancer presents second in the ranking of causes of death in the world, with 9.6 million deaths or, 1 for every 6 deaths, in 2018. Approximately $70 \%$ of the cases that lead to death occur in low and middle income countries [1]. It is estimated that the number of cancer cases in 2040 will be of 24.9 thousand [2]. Among these numbers, bladder cancer is the $7^{\text {th }}$ most common type in men and the $17^{\text {th }}$ most common type in women [3]. It has a higher prevalence in the western portion of the globe and high recurrence being a major problem for health systems [4].

Chemotherapy and radiotherapy are the main treatments applied against cancer, however, they are not completely effective, and metastases continue to appear as the main cause of death. This is due to the low selectivity of this type of treatment for tumor cells, which leads to the appearance of several and devastating side effects [5].

In this way, new treatments are sought and the use of bacteria was established with the studies of the physician William Colley, who developed a safe therapy through a mixture of Streptococcus pyogenes and Serratia marcescens killed by the heat, in order to successfully treat sarcoma, carcinoma, lymphoma, melanoma and myeloma [6]. Such procedures are the basis of recent advances in cancer immunotherapy using attenuated bacterial strains.

Features such as selective accumulation in the tumor, replication and destruction of tumors in rodents, induction of an immune system-mediated antitumor response, targeting small metastatic nodules scattered throughout the body and inhibiting their growth [7], have made this approach stand out in recent years. The explanation of the targeting to the tumor being chemotaxis essential for this process, refers to the tumor tissue as a source of highly concentrated nutrients and in addition, it can avoid the clearance by the host's immune system $[8,9]$.

The attenuated Salmonella enteric serotype Typhimurium is widely studied as a live bacterial vector, due to its ready availability and ease of genetic manipulation. Due to the fact that $S$. typhimurium is able to grow under aerobic and anaerobic conditions, it can colonize large and small tumors [9]. This attenuated species also manages to prevent tumor growth in a wide range of human tumors that have been implanted in mice and in mouse tumors, in which tumor growth inhibition has occurred for long periods [10].

One of the most used strains of S. typhimurium is SL3261, which has the attenuation of the aroA gene, in which there is a deletion of this gene that causes the bacteria to become deficient in the synthesis of certain aromatic compounds and starts to request them externally. It is worth noting that such compounds are not found in mammalian tissues, making this attenuation very safe and, therefore, widely used [11-13].

One of the challenges when using bacterial lineage as vectors is a possible toxicity, which can lead to smaller doses decreasing the effectiveness [14]. Another factor that can negatively affect cancer gene therapy is the absence of specific therapy targeting directly at the solid tumor [14].

To try to overcome these limitations, the use of bacteria genetically modified to express a specific therapeutic gene is recommended, since by producing the protein of interest specifically in the tumor microenvironment, these bacterial vectors can provide a powerful adjuvant therapy for various cancer treatment. Preclinical studies have shown the ability of different bacterial strains to transport and amplify genes that encode therapeutic agents specifically within tumors [15].

The proteins IL-2 (Interleukin 2) and TRAIL (TNF-related apoptosis-inducing ligand) are known for their anti-tumor effect having many studies that corroborate thatis, and can be expressed by bacterial vectors in the tumor microenvironment [16-18]. IL-2 stimulates the proliferation of TCD- 4 cells, which leads to the activation of TCD-8, NK and dendritic cells $[16,19]$. Studies have shown that IL-2 can lead to complete and long-lasting regressions in patients with metastatic melanoma and kidney cancer [16]. However, the use of high doses of IL-2 has resulted in severe toxicity in many patients [20]. To reverse this situation, an attenuated strain of $S$. typhimurium was developed that synthesizes IL-2 locally in areas of 
bacterial colonization, which demonstrated that the IL-2 produced by $S$. typhimurium has biological activity, and that its administration results in significantly less liver metastases from colon adenocarcinoma in a murine model [20].

TRAIL is an apoptosis-inducing ligand related to TNF [17] that has the ability to induce cell death by apoptosis through interaction with its receptors $[17,18]$. Studies have shown that TRAIL induced apoptosis in a wide range of transformed or tumor cells, but not normal cells, making this protein promising in cancer therapy. TRAIL has rapid renal clearance and short half-life and can also cause liver cell death [21,22].

Therefore, the use of attenuated bacteria such as $S$. typhimurium that direct the production of TRAIL and IL-2 in the tumor microenvironment can reduce possible toxic side effects in normal cells, while maintaining high intratumor concentrations of the protein. Due to the high recurrence and malignancy of the bladder tumor, the objective of this study was to evaluate the cytotoxic and apoptotic effect of the SL3261 strain synthesizing IL-2, TRAIL and the MIX of proteins in MB49 murine bladder tumor cells in the periods of 24 and 48 hours of treatment.

\section{Materials and Methods}

\section{Recombinant strains of S. typhimurium}

Three recombinant strains of S. typhimurium provided by Dr. Luciana Camillo from the Laboratório de Inflamação e Doenças Infecciosas, from Universidade Federal de São Carlos, UFSCar, São Carlos - SP, Brazil. The first strain used was SL3261, attenuated by deleting the aroA gene and without a plasmid inserted. The other strains, SL3261_IL-2 and SL3261_TRAIL were constructed to carry a plasmid encoding murine gene sequences of proteins IL-2 and TRAIL, synthesized by the company Biomatik, which were cloned first in E. coli DH5 $\alpha$ and later in SL3261 [23].

TRAIL was produced fused to the fluorescent protein EmGFP (Emerald green fluorescent protein), while IL-2 was fused to YFP (yellow fluorescent protein). The EmGFP and YFP genes were added to the $\mathrm{N}$-terminal portion of the protein of interest and fused in frame [24].

For the insertion of these genes the plasmid chosen was pAE containing the nirB promoter, the expression of which is induced in anaerobiosis and already used for this type of approach [25, 26]. During the cloning process, the plasmids were extracted using commercial plasmid extraction kits and the transformations made by thermal shock. The clones were confirmed by digestion with specific restriction enzymes and agarose gel analysis, comparing with the molecular marker [23].

\section{Cultivation and maintenance of SL3261 strains}

Each bacterial strain was stored in $10 \%$ glycerol and kept at $-80^{\circ} \mathrm{C}$. The medium used is LB $(10 \mathrm{~g}$ of tryptone, $5 \mathrm{~g}$ of yeast extract and $5 \mathrm{~g}$ of $\mathrm{NaCl}$ for 1 liter of distilled water) containing $100 \mu \mathrm{g} / \mathrm{ml}$ of ampicillin for lines SL3261_IL-2 and SL3261_TRAIL. For the plates containing LB agar medium, a transfer loop was removed from the bacterial suspension and the plate was striated. The cultivation was maintained at $37^{\circ} \mathrm{C}$ for 48 hours.

For the pre-inoculum an isolated colony was inoculated in $20 \mathrm{ml}$ of liquid LB medium. The culture was kept overnight ( 16 hours) at $37^{\circ} \mathrm{C}$ and $200 \mathrm{~g}$ in a screw flask. Then, the OD was read at $600 \mathrm{~nm}$ and an aliquot corrected for OD 0.1 was added in $30 \mathrm{ml}$ of LB medium for the cultivation of the inoculum in Erlenmeyer. The cultivation was maintained at $37^{\circ} \mathrm{C}$ and at $200 \mathrm{~g}$. until reaching OD equal to 0.4 .

Thereafter, the expression of IL-2 and TRAIL proteins was induced by anaerobiosis for 72 hours at $37^{\circ} \mathrm{C}$ and in $200 \mathrm{~g}$. For the anaerobic condition, screw flasks with culture medium up to the mouth and sealed with Parafilm $\mathrm{M} 囚$ were used. The culture was then centrifuged at $10000 \mathrm{~g}$, for $20 \mathrm{~min}$ at $4{ }^{\circ} \mathrm{C}$. The pellet was discarded and the supernatant to be used in the in vitro experiments was sterilized in a syringe filter with a $0.22 \mu \mathrm{m}$ pore. For each in vitro test, fresh bacterial cultures were prepared (Supplementary Fig. $1 \mathrm{~A}$ - for all supplementary material see www.cellphysiolbiochem.com). 


\section{Cellular Physiology Cell Physiol Biochem 2021;55:460-476 \\ \begin{tabular}{ll|l} 
DOl: 10.33594/000000398 & $\begin{array}{l}\text { O } 2021 \text { The Author(s). Published by } \\
\text { Cell Physiol Biochem Press GmbH\&Co. KG }\end{array}$ \\
\cline { 2 - 3 }
\end{tabular} \\ de Lima Fragelli et al.: IL-2 and TRIL Synthesized by Salmonella against Bladder Tumor Cells}

Fluorescence reading of bacterial strains

To measure the fluorescence emission of the IL- 2 and TRAIL proteins in the bacterial culture, and to verify their expression and release by the SL3261, $100 \mu \mathrm{l}$ of the culture was added in a 96-well plate. The fluorescence emission was read at $527 \mathrm{~nm}$ for IL-2 and $509 \mathrm{~nm}$ for TRAIL on the Spectra MAX i3TM plate spectrophotometer (Molecular Devices).

\section{Dosage of IL-2 and TRAIL levels by ELISA}

For the analysis of the TRAIL and IL-2 proteins production by the SL3261_TRAIL and SL3261_IL-2 lines, samples of the cell culture supernatant overnight were used and the supernatant from the culture of the empty SL3261 line was used for comparison. The procedures were followed according to the manufacturer (Thermo Fisher Scientific $\AA$ ). The samples were placed in a 96-well plate and incubated for 16 hours at $4{ }^{\circ} \mathrm{C}$. Then the plate was blocked with milk proteins for 2 hours at room temperature. Anti IL-2 and anti TRAIL capture antibody were added, and incubate for 2 hour at $37^{\circ} \mathrm{C}$. The secondary antibody coupled with peroxidase enzyme was added and incubated for 2 hours at $37^{\circ} \mathrm{C}$. The enzyme substrate (3,3',5,5'-Tetramethylbenzidine, TMB) was added to the wells revealing the reaction. The absorbance reading was measured at $450 \mathrm{~nm}$ on a plate spectrophotometer (Thermo Scientific $^{\mathrm{TM}}$ Multiskan $^{\mathrm{TM}}$ GO Microplate Spectrophotometer).

\section{MB49 cell cultivation and experimental design}

Murine bladder cancer cell line, MB49, was maintained in medium bottles containing Dulbecco's Modified Eagle's Medium (DMEM, Sigma-ALDRICH, USA) supplemented with $10 \%$ fetal bovine serum (SFB, LGC Biotechnology) \% of $\mathrm{CO} 2$ and kept under passage.

The 6 groups proposed and the treatment established are shown in Table 1. For 96-well plate experiments, $1 \times 10^{4}$ cells per well were inoculated. For 24 -well plate assays, $1 \times 10^{5}$ (cytometer analysis) and $1 \times 10^{3}$ cells per well (clonogenic assay) were inoculated. For fluorescence testing, a black 96-well plate was used. The exposure time to treatments was 24 and 48 hours and was followed by the tests performed (Supplementary Fig. 1B).

\section{Cell viability through the MTT assay}

To assess the integrity of mitochondrial function, the Tetrazolium 3-(4,5-dimethylthiazol-2-yl)-2,5diphenylbromide (MTT) colorimetric method (SIGMA-ALDRICH, USA) [27] was performed. The analysis takes place by measuring formazan crystal formation. The greater the production of these crystals, the greater the cell viability. After the exposure times, the wells were washed 2 times with $1 \mathrm{x}$ PBS (phosphate buffer saline) and $200 \mu \mathrm{l}$ of the MTT solution at $0.5 \mathrm{mg} / \mathrm{ml}$ was added for 3 hours at $37{ }^{\circ} \mathrm{C}$ and $5 \% \mathrm{CO}_{2}$. Then, the reagent solution was removed and $100 \mu \mathrm{l}$ of the DMSO diluent was added per well, followed by the absorbance reading at $570 \mathrm{~nm}$ in a spectrophotometer (Thermo Scientific ${ }^{\mathrm{TM}}$ Multiskan ${ }^{\text {TM }}$ GO Microplate Spectrophotometer). The percentage of cytotoxicity was obtained by comparing the data with the CTRLgroup according to the equation below:

$$
\% \text { cytotoxicity }=\frac{\text { Experimental group } \times 100}{\text { CTRL }- \text { group mean }}
$$

\section{Cell morphology by optical microscopy}

For the analysis of cell morphology, an optical microscope was used. Axiovert 40 CFL (Zeiss), with a 10X objective lens, which images were captured using the coupled camera model LOD-3000 (Bio Focus) and analyzed by the software Future WinJoe ${ }^{\mathrm{TM}}$ version 2.0 . 


\section{Cellular Physiology Cell Physiol Biochem 2021;55:460-476 \\ \begin{tabular}{l|l|l}
\hline DOl: 10.33594/000000398 & (c) 2021 The Author(s). Published by
\end{tabular} \\ \begin{tabular}{l|l} 
Published online: 7 August 2021 & Cell Physiol Biochem Press GmbH\&Co. KG \\
\hline
\end{tabular} \\ de Lima Fragelli et al.: IL-2 and TRIL Synthesized by Salmonella against Bladder Tumor Cells}

\section{Colony formation by clonogenic assay}

Using the clonogenic assay [28], the ability of MB49 cells to recover after the proposed treatment was assessed. After the exposure times, the supernatant was discarded and new culture medium was added. After 7 days of recovery, the cells were fixed with methanol and stained with $0.1 \%$ violet crystal. The wells were photographed and colony counting was performed using ImageJ software version $1.53^{\mathrm{a}}$ [29].

Damage to the cell membrane via the release of the enzyme lactate dehydrogenase (LDH)

Possible damage to the cell membrane was assessed by measuring LDH release according to the CyQuant ${ }^{\mathrm{TM}}$ LDH Cytotoxicity Assay Kit (Invitrogen). After the exposure times, the supernatant from each group was collected and $50 \mu \mathrm{l}$ was added to a new plate. Then, $50 \mu \mathrm{l}$ of the reagent solution was added to each well for 30 minutes at $37{ }^{\circ} \mathrm{C}$ and $5 \% \mathrm{CO}_{2}$. The absorbance was read at $490 \mathrm{~nm}$ and at $690 \mathrm{~nm}$ on the plate spectrophotometer (Thermo Scientific ${ }^{T M}$ Multiskan $^{T M}$ GO Microplate Spectrophotometer). To determine LDH activity, the values obtained at $680 \mathrm{~nm}$ from $490 \mathrm{~nm}$ were subtracted and the $\%$ cytotoxicity was calculated using the formula:

$$
\text { LDH release (\%) }=\frac{\text { Experimental group }- \text { spontaneous LDH activity } x 100}{\text { Maximum LDH activity }- \text { spontaneous LDH activity }}
$$

The wells of spontaneous LDH activity contained $10 \mu \mathrm{l}$ of water and the maximum LDH activity contained $10 \mu$ l of lysis solution.

\section{Production of Nitric Oxide (NO) by the Griees Reaction}

To measure the NO production, the Griess reaction was carried out [30,31] which measures the production of the nitrite ion $\left(\mathrm{NO}_{2}-\right)$. After the exposure times, $50 \mu \mathrm{l}$ of the supernatant was added to a new plate followed by the addition of $50 \mu \mathrm{l}$ of the Griees solution (1:1 mixture of solution $\mathrm{A}$ [ $1 \%$ sulfanilamide in $5 \%$ phosphoric acid] and solution B [0,1\% N-1-naphthylethylenediamine dihydrochloride]) for 15 minutes at room temperature. The absorbance reading was performed at $540 \mathrm{~nm}$ on a spectrophotometer (Thermo Scientific $^{\text {TM Multiskan }}{ }^{\text {TM }}$ GO Microplate Spectrophotometer). The concentration of nitrite in the supernatant was quantified from a standard curve with known concentrations of nitrite in $\mathrm{mM}$ described in the kit.

High resolution images with the fluorescent markers acridine orange (LA) and propidium iodide (IP)

To identify the type of cell death induced by the presence of the proteins, fluorescence image analysis was performed using reagents LA and IP. After the exposure times, the supernatant from the wells was removed and $30 \mu \mathrm{l}$ of LA/IP $0.1 \%$ (1:1) were added to each well for 15 minutes at room temperature protected from light. Then, the wells were washed with 1x PBS and DMEM medium without SFB and phenol was added. The images were obtained using an automated high resolution epifluorescent microscopy system ImageXpress Micro (Molecular Devices) with 40X objective lens and FITC and TexasRed filters with image overlay.

Apoptosis by flow cytometry with the markers PE Anexina V and 7AAD

Cell death due to apoptosis was also assessed by means of PE Anexina V (BD Biosciences detection kit). After the exposure times, the plates were centrifuged and washed with 1x PBS and antibodies PE Anexin V and 7AAd [1:1] (1 $\mu \mathrm{l} /$ well in 1:10 binding buffer) were added. The reaction occurred for 15 minutes at room temperature protected from light. Then, the cells were removed with a scraper and resuspended in microtubes with $300 \mu \mathrm{l}$ of binding buffer. The reading was performed on an Accuri ${ }^{\text {TM }} \mathrm{C} 6 \mathrm{BD}$ Biosciences flow cytometer, selecting a gate with 10,000 events. The analysis was performed using FlowJo ${ }^{\mathrm{TM}}$ software version XV (BD Biosciences).

\section{Statistical analysis}

The data obtained in this study were expressed as mean \pm SD and analyzed using GraphPad Prism 7.0 (San Diego, California, USA). The entire study was carried out in biological triplicates minimum, in three independent experiments. The discrepant data were identified through the Grubbs analysis, followed by the Shapiro-Wilk test to verify the parametric or non-parametric nature of the data. Therefore, the ANOVA test (analysis of variance) was applied to the parametric data and the Tukey multiple comparisons post-test 


\section{Cellular Physiology Cell Physiol Biochem 2021;55:460-476 \\ \begin{tabular}{ll|l} 
and Biochemistry 10.33594/000000398 & $\begin{array}{l}\text { D } 2021 \text { The Author(s). Published by } \\
\text { Published online: } 7 \text { August } 2021\end{array}$ \\
\cline { 2 - 3 } & Cell Physiol Biochem Press GmbH\&Co. KG
\end{tabular} \\ de Lima Fragelli et al.: IL-2 and TRIL Synthesized by Salmonella against Bladder Tumor Cells}

(results were presented in mean and standard deviation). For nonparametric data, the Kruskal-Wallis test and the Dunn multiple comparison post-test were used (results were presented as the median with the upper and lower quartiles: Me [Q1; Q3]). For the analysis of only two groups, the t test was applied, and for non-parametric data the Mann-Whitney post test was applied and for parametic data the unpaired post test was applied. Statistical significance was established at $\mathrm{p}<0.05$.

\section{Results}

The Fig. 1A and 1B show the levels of IL-2 and TRAIL measured by the ELISA method. It was observed a significant difference in the increase of IL-2 levels when compared to the SL3261 group in the plate sensitized with anti IL-2. There was also a significant difference in the increase in TRAIL levels when compared to the SL3261 and SL3261_IL-2 groups on the TRAIL-sensitized plate. Fig. 1C and 1D show the fluorescence emissions of the YFP and EmGFP proteins from the SL3261, SL3261_IL-2 and SL3261_TRAIL strains. There was a significant difference in the values found in the SL3261_IL-2 and SL3261_TRAIL when compared to the SL3261. The higher value found showed that the induction of YFP and EmGFP proteins by anaerobiosis was efficient and that there were proteins synthesized and released in the culture medium.

Values obtained by the MTT assay showing the percentage of cell viability after 24 hours and in 48 hours are demonstrated in the Fig. 2A and 2B. The cytotoxicity caused by the proteins IL-2, TRAIL and the MIX of the proteins was presented after 24 hours, with a significant difference when compared to the groups CTRL-, CTRL LB and SL3261. Within 48 hours, the same decrease in cell viability remained. The three treatments decreased the viability for the MB49 cell, with the TRAIL protein showing greater cellular damage.

This cytotoxic effect is also observed in optical microscopy photos of MB49 cells after 24 hours (Fig. 3A) and 48 hours (Fig. 3B) of treatment. After 24 hours, the CRTL-, CTRL LB and SL3261 groups showed a higher number of cells with preserved morphology when compared to the groups treated with IL-2, TRAIL and the MIX of proteins, which in addition to a smaller number of cells, the morphology was altered. After 48 hours, the CRTL-, CTRL LB and SL3261 groups had lower number of cells when compared to 24 hours, however the cell morphology was preserved. The cells exposed to IL-2, TRAIL and MIX were in smaller number of cells and their morphology was even more modified.

Fig. 1. ELISA dosage and fluorescence emission of IL-2 and TRAIL proteins in bacterial culture. Quantitative data analysis. (A, B) Levels of IL-2 and TRAIL dosage by ELISA. (C, D) Detection of IL-2 and TRAIL proteins in the SL3261 culture supernatant after sensitizing the plate with $100 \mu \mathrm{l} /$ well. The assay was carried out at least in triplicate, in three independent experiments. Groups: SL3261, culture supernatant + antibody against IL-2 or TRAIL; SL3261_IL-2, culture supernatant + antibody against IL-2; SL3261_TRAIL, culture supernatant + antibody against TRAIL. $\left(^{*}\right)$ vs SL3261; * $\mathrm{p}<0.05$; $^{* *} \mathrm{p}<0.01$; $^{* * *} \mathrm{p}<0.001 ;\left(^{\circ}\right)$ vs SL3261_IL-2; ${ }^{\circ} \mathrm{p}<0.05$. The results were presented as the median with the upper and lower quartiles: Me [Q1; Q3].

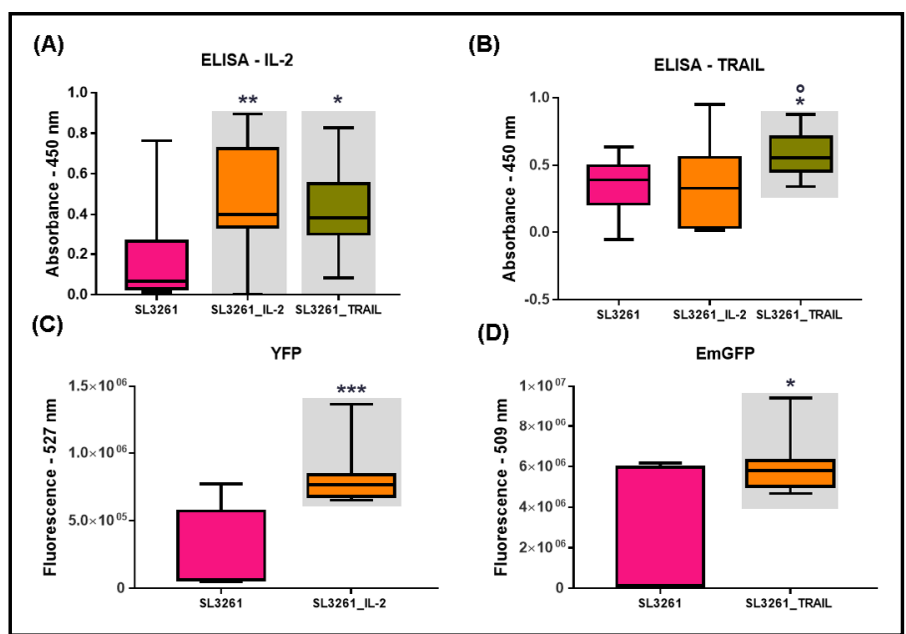

(B)

(D) 
Fig. 2. Cytotoxicity in $\%$ effect on MB49 cells after 24 and 48 hours of explosion to IL-2, TRAIL and MIX. Quantitative data analysis. (A). Cytotoxicity in \% of IL2, TRAIL and MIX proteins after 24 hours of exposure.
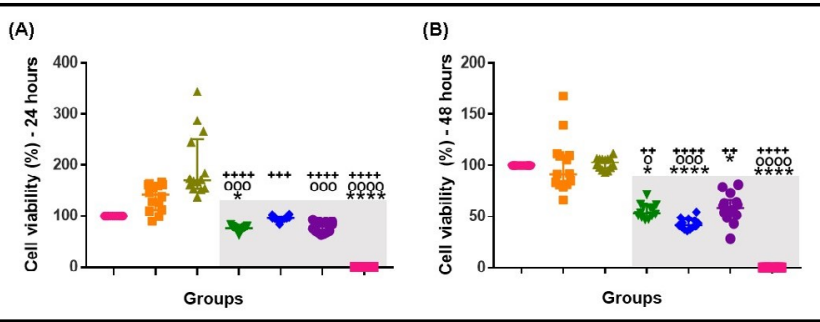
(B). Cytotoxicity in \% of IL-2, TRAIL and MIX proteins after 48 hours of exposure to the treatments. The assay was carried out at least in triplicate, in three independent experiments. Groups: CTRL-, no treatment; CTRL LB, DMEM + LB; SL3261, DMEM + SL3261; SL3261_IL-2, DMEM + SL3261- IL-2 plasmid; SL3261_TRAIL, DMEM and + SL3261-TRAIL plasmid; SL3261_MIX, DMEM + SL3261 - IL-2 + TRAIL plasmid; CTRL+, DMEM + extran 5\%. (*) vs CTRL-; ${ }^{*} \mathrm{p}<0.05 ;{ }^{* * * *} \mathrm{p}<0.0001$. $\left({ }^{\circ}\right)$ vs CTRL LB; ${ }^{\circ} \mathrm{p}<0.05 ;{ }^{\circ \circ \circ} \mathrm{p}<0.001 ;{ }^{\circ 00 \circ} \mathrm{p}<0.0001$. (+) vs SL3261; ++ $\mathrm{p}<0.001$; $++++p<0.0001$. The results were presented as the median with the upper and lower quartiles: Me [Q1; Q3].

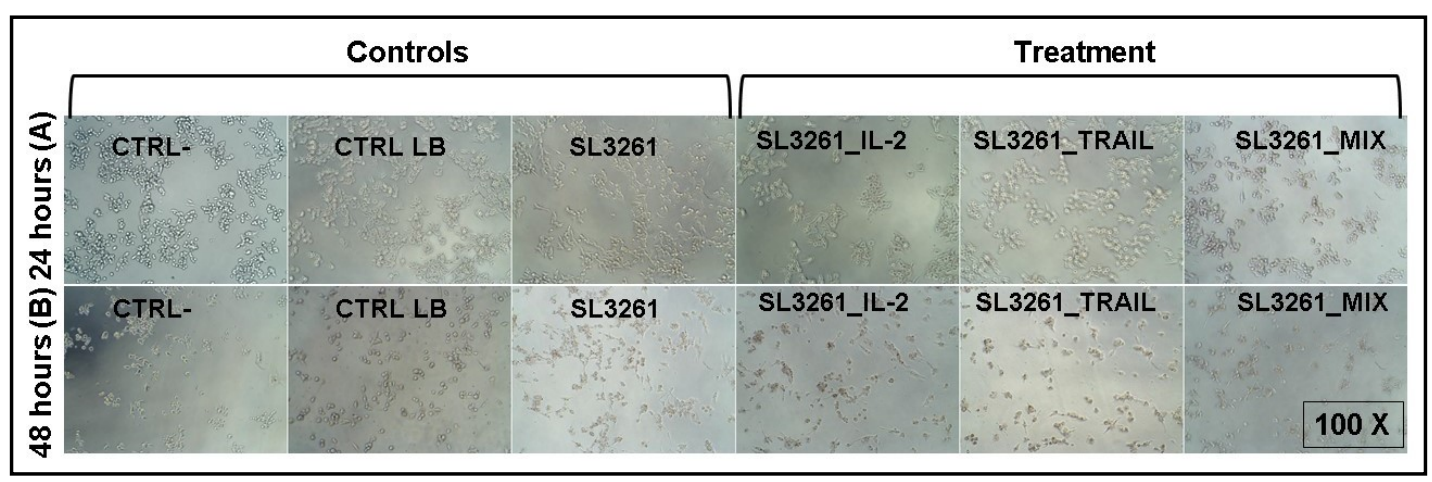

Fig. 3. Optical microscopy of MB49 tumor cell morphology. Representative data. (A) MB49 morphology after 24 hours of exposure to the treatments. (B) MB49 morphology after 48 hours of exposure to the treatment. Increase: $100 \mathrm{X}$.

The Fig. $4 \mathrm{~A}$ and $4 \mathrm{~B}$ show the number of colonies formed, and at both times, there is a significant difference in the number of colonies formed in the groups. Both in 24 and 48 hours, MB49 cells formed a reduced number of colonies in groups SL3261_IL-2, SL3261_ TRAIL and SL3261_MIX when compared to groups CRTL-, CTRL LB and SL3261, with a statistical difference greater in 48 hours. The Fig. 4C and 4D wells photographs from all groups of the clonogenic assay showing the recovery of MB49 cells through the formation of colonies after treatment with IL-2, TRAIL and MIX proteins after 24 and 48 hours.

In Fig. 5A and 5B show the release of the enzyme LDH in the groups CRTL-, CTRL LB, SL3261, SL3261_IL-2, SL3261_TRAIL and SL3261_MIX, after 24 and 48 hours of exposure to proteins IL-2, TRAIL and MIX of the proteins. The groups treated with TRAIL and MIX showed a significant difference when compared to the groups CTRL- and CTRL LB in the period of 24 hours. Within 48 hours the significant difference occurs in the MIX group when compared to the CTRL- and CTRL LB groups. The data show that in the groups treated with TRAIL and MIX in both periods analyzed, LDH is released, showing damage to the MB49 cell membrane, being this damage greater in the 24-hour period. The SL3261_IL-2 group showed higher levels of cytotoxicity in 48 hours, but with no significant difference observed.

Production of NO by the MB49 cells after treatment with IL-2, TRAIL and MIX of the proteins in the periods of 24 and 48 hours is shown in Fig. 5C and 5D. The cells exposed to TRAIL and MIX had a significant increase in NO production when compared to the CTRL- and CTRL LB groups within 24 hours. In 48 hours, the significant increase occurred in the groups SL3261_TRAIL and SL3261_MIX when compared to the groups CRTL-, CTRL LB and SL3261. In both periods there was a significant increase in NO production in the group treated with IL-2, but there is no significant difference observed. 


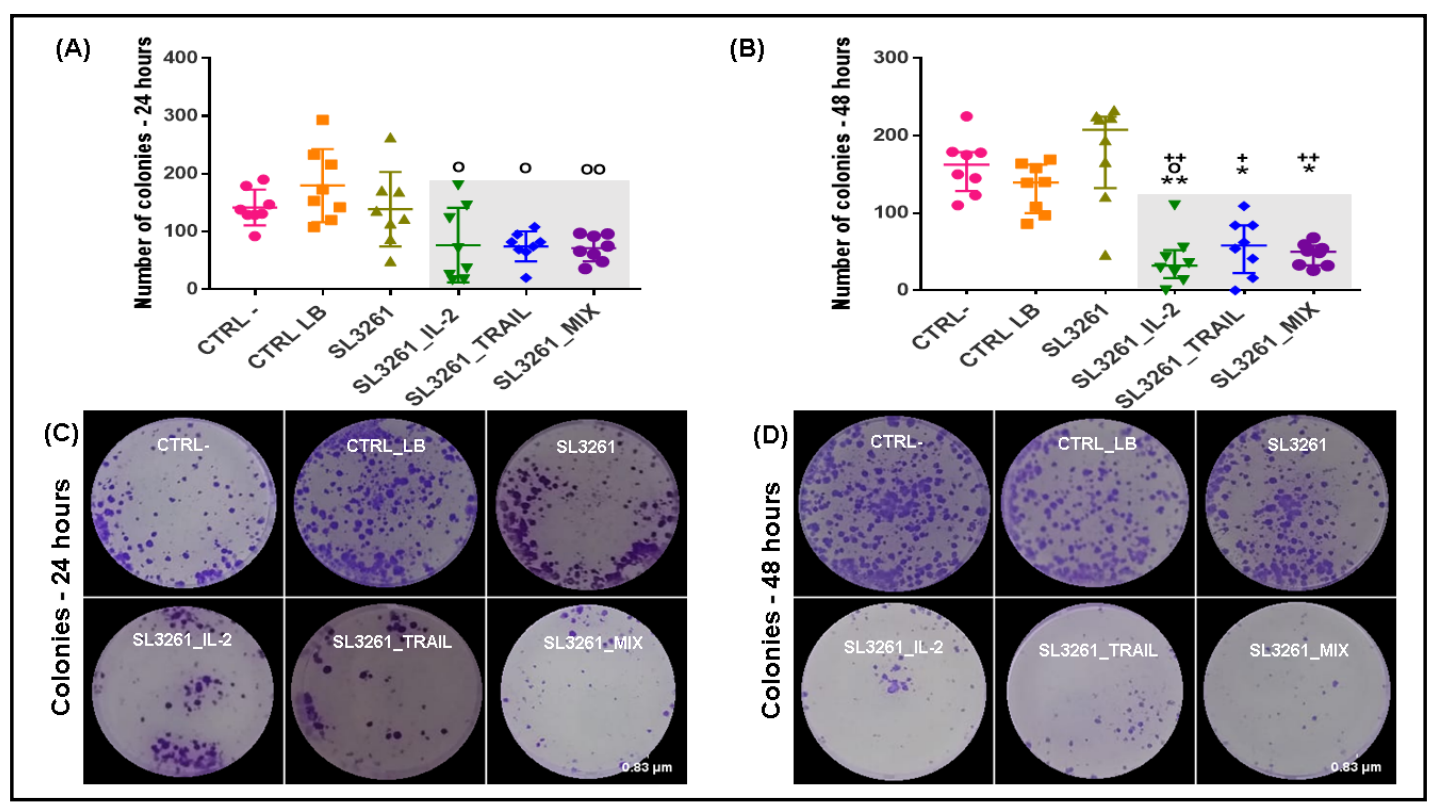

Fig. 4. Cell recovery via colony formation. (A, B). Number of colonies formed. Quantitative data analysis. (C, D). Wells photographs from all groups showing colonies formed of MB49 tumor cells after 7 days of recovery. Representative data. The assay was carried out at least in triplicate, in three independent experiments. $\left({ }^{*}\right)$ vs CTRL-; ${ }^{*} \mathrm{p}<0.05 ;{ }^{* *} \mathrm{p}<0.01$. $\left({ }^{\circ}\right)$ vs CTRL LB; ${ }^{\circ} \mathrm{p}<0.05 ;{ }^{\circ} \mathrm{p}<0.01$. (+) vs SL3261; $+\mathrm{p}<0.05 ;++\mathrm{p}<0.01$. The results were presented as the median with the upper and lower quartiles: Me [Q1; Q3].

Fig. 5. Lactate dehydrogenase $(\mathrm{LDH})$ release and Production of nitric oxide (NO). Quantitative data analysis. (A, B) Percentage of cell viability by quantifying LDH released 24 and 48 hours after exposure to treatments. (C, D) Concentration of nitric oxide (NO) 24 and 48 hours after exposure to treatments. The assay was carried out at least in triplicate, in three independent experiments. Groups:

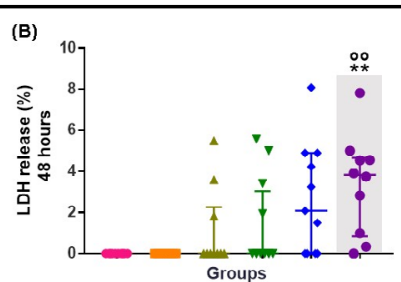

(D)

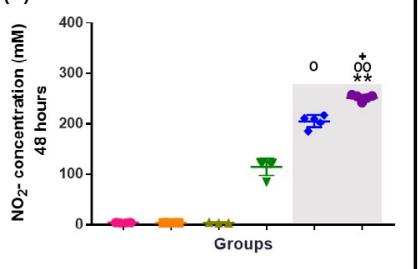

CTRL-, no treatment; CTRL LB, DMEM + LB; SL3261, DMEM + SL3261; SL3261_IL-2, DMEM + SL3261- IL-2 plasmid; SL3261_TRAIL, DMEM and + SL3261-TRAIL plasmid; SL3261_MIX, DMEM + SL3261 - IL-2 + TRAIL plasmid; CTRL+, DMEM + extran 5\%. (*) vs CTRL-; ${ }^{*} \mathrm{p}<0.05$; ${ }^{* *} \mathrm{p}<0.01$. ( $\left.{ }^{\circ}\right)$ vs CTRL LB; ${ }^{\circ} \mathrm{p}<0.05 ;^{\circ}{ }^{\circ} \mathrm{p}<0.01$; ${ }^{\circ 0 \circ} \mathrm{p}<0.001 ;{ }^{\circ 000} \mathrm{p}<0.0001$. (+) vs SL3261; $+\mathrm{p}<0.05 ;++++\mathrm{p}<0.0001$. The results were presented as the median with the upper and lower quartiles: Me [Q1; Q3]. 
High resolution epifluorescent microscopy images of MB49 cells are shown in the Fig. 6A and 6B after 24 and 48 hours of exposure to IL-2, TRAIL and MIX proteins and stained with acridine orange, which marks living and dead cells and emits green and with propidium iodide that marks dead cells in which the reddish cytoplasm indicates initial apoptosis and the reddish nucleus indicates apoptosis. The overlapping of images shows that the groups CTRL-, CTRL LB and SL3261 in both 24 and 48 hours did not present cellular damage, with preserved morphology, green color, and high number of cells. The SL3261_IL-2, SL3261_ TRAIL and SL3261_MIX groups have altered morphology, decreased number of orange cells and nuclei showing late apoptosis, both in 24 and 48 hours.

Dot plot graphs obtained through flow cytometry of the groups CTRL-, CTRL LB, SL3261, SL3261_IL-2, SL3261_TRAIL and SL3261_MIX in MB49 cell culture in 24 and 48 hours are showed in the Fig. 7A and 7B. The data presented are representative, showing a single reading from each group, since the sample number is $n=8$. The graphs show the fluorescence in \% of each marker, with 7-AAD on the y-axis and PE Anexina V on the X-axis. The cells that are considered viable are PE Annexin V and 7-AAD negative. The cells that are in early apoptosis are PE Annexin $\mathrm{V}$ positive and 7-AAD negative, while cells that are in late apoptosis or already dead are both PE Annexin V and 7-AAD positive. The Fig. 7C and 7D are representative of histograms showing the fluorescence peak emission of the respective markers, according to each group analyzed in both 24 hours and 48 hours. At both times the emission peaks of the SL3261_IL-2, SL3261_TRAIL and SL3261_MIX groups are significantly higher than the peaks of the CTRL-, CTRL LB and SL3261 groups.

Cell analysis quantified in \% via flow cytometry of MB49 cells 24 and 48 hours after treatment with IL-2, TRAIL and MIX of proteins are represented in Fig. 8. The data presented were compensated using controls with heat-killed MB49 cells labeled with Pe Anexin V and 7AAd, separately and with the control of live MB49 cells double-labeled concomitantly. Fig. $8 \mathrm{~A}$ and $8 \mathrm{D}$ indicate that there was a significant increase in $\%$ of initial and late apoptotic cells. In 24 hours (8A) in the SL3261_IL-2, SL3261_TRAIL and SL3261_MIX groups, there was an increase in late apoptotic cells when compared to the CTRL- group. In the SL3261_IL-2 and SL3261_MIX groups there was a significant increase in apoptotic cells when compared to the CTRL- group. The groups CTRL LB and SL3261 do not show an increase in \% of late and initial apoptotic cells. In 48 hours (Fig. 8D), when comparing the CTRL- group with the other groups, the SL3261_TRAIL and SL3261_MIX groups showed a significant increase in the \% of late apoptotic cells, and the SL3261_IL-2, SL3261_TRAIL and SL3261_MIX groups obtained a significant increase of \% of initial apoptotic cells. In Fig. 8B and 8C, the comparison between initial and late apoptotic cells in 24 and 48 hours using the average number of cells is represented by the heatmap graph. This graph allows to understand which group had more initial or late apoptotic cells according to the color (green represents the minimum and red represents the maximum reached).

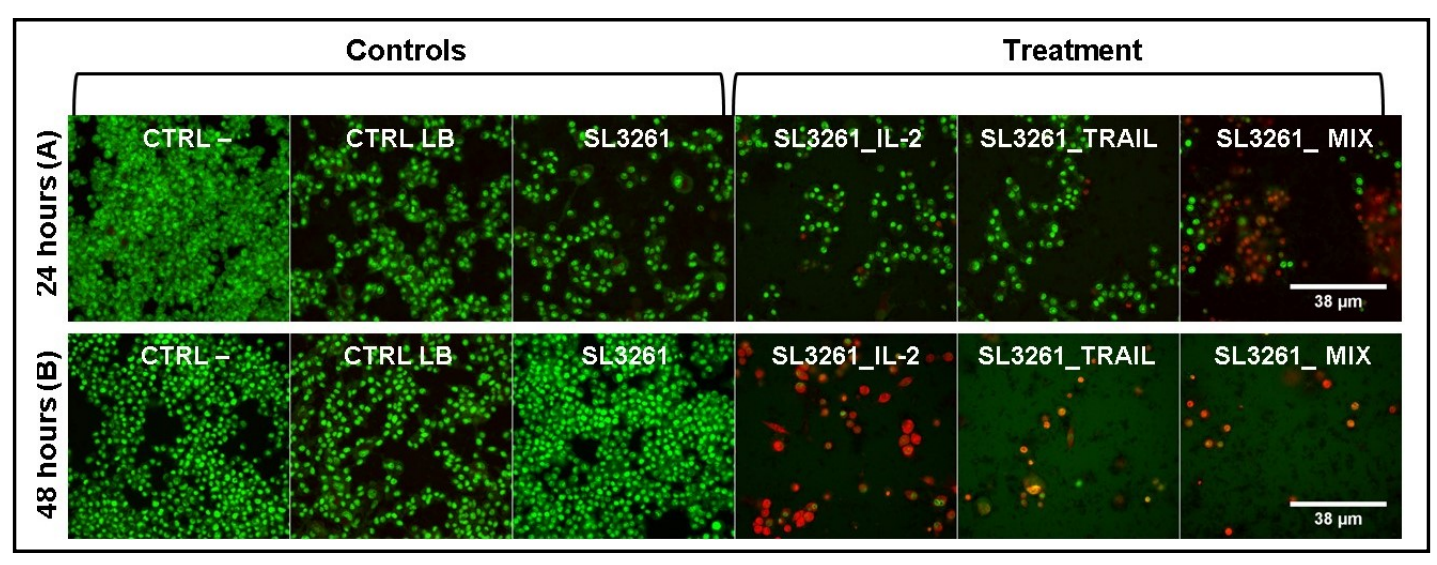

Fig. 6. High resolution fluorescence images for analysis of cell death by apoptosis. Representative data. (A, B). Images obtained using an automated high resolution epifluorescent microscopy system of MB49 cells stained with LA and IP fluorophores. Increase: $400 \mathrm{X}$. 


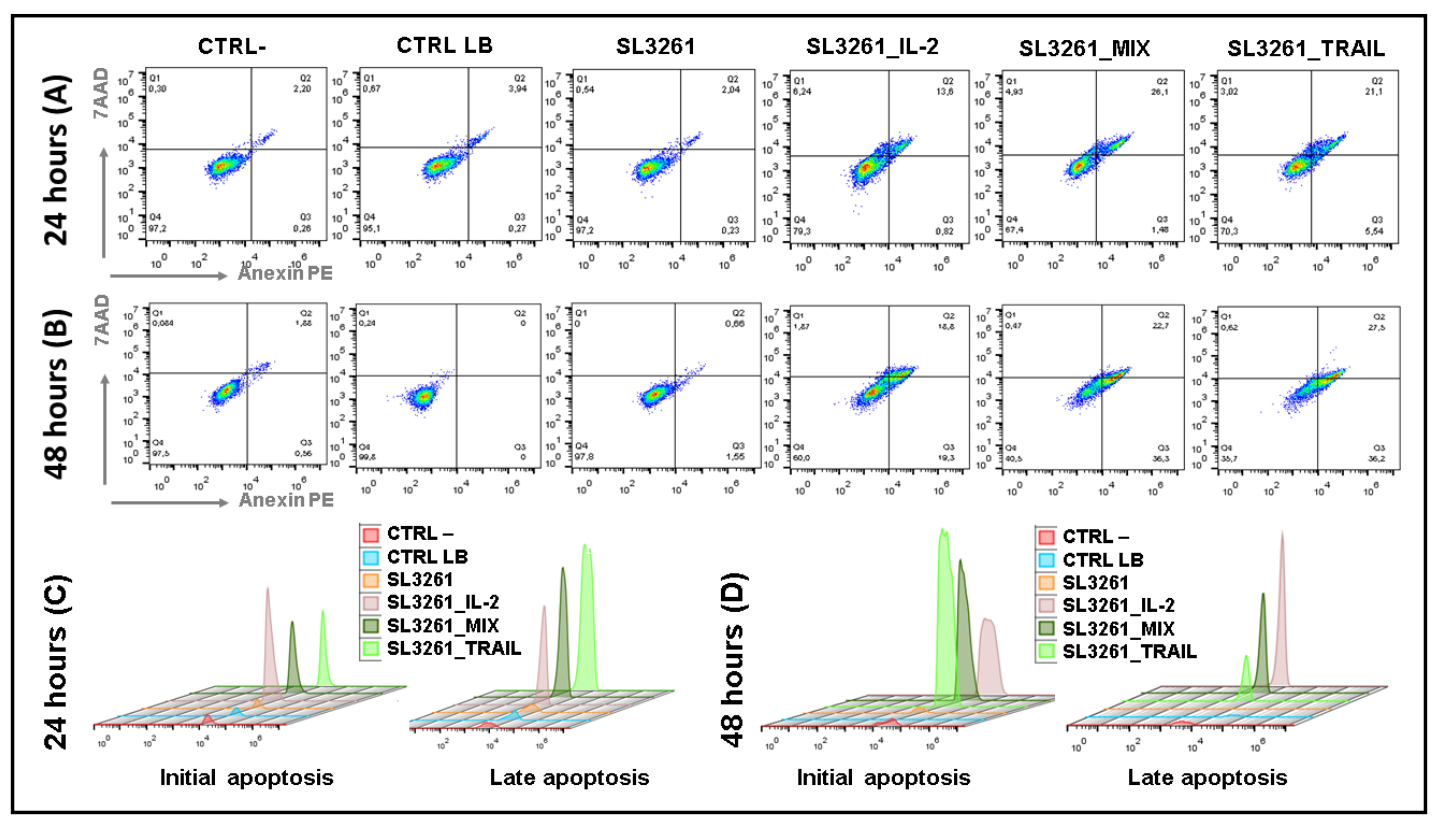

Fig. 7. Representative analysis of initial and late apoptosis by flow cytometry. Representative data. (A, B) the Dot plot graphs obtained through flow cytometry. Quantitative data analysis. (C, D) The histogram graph represents each peak of fluorescence emission. The assay was carried out at least in triplicate, in three independent experiments. Groups: CTRL-, no treatment; CTRL LB, DMEM + LB; SL3261, DMEM + SL3261; SL3261_IL-2, DMEM + SL3261-IL-2 plasmid; SL3261_TRAIL, DMEM and + SL3261-TRAIL plasmid; SL3261_ MIX, DMEM + SL3261 - IL-2 + TRAIL plasmid.

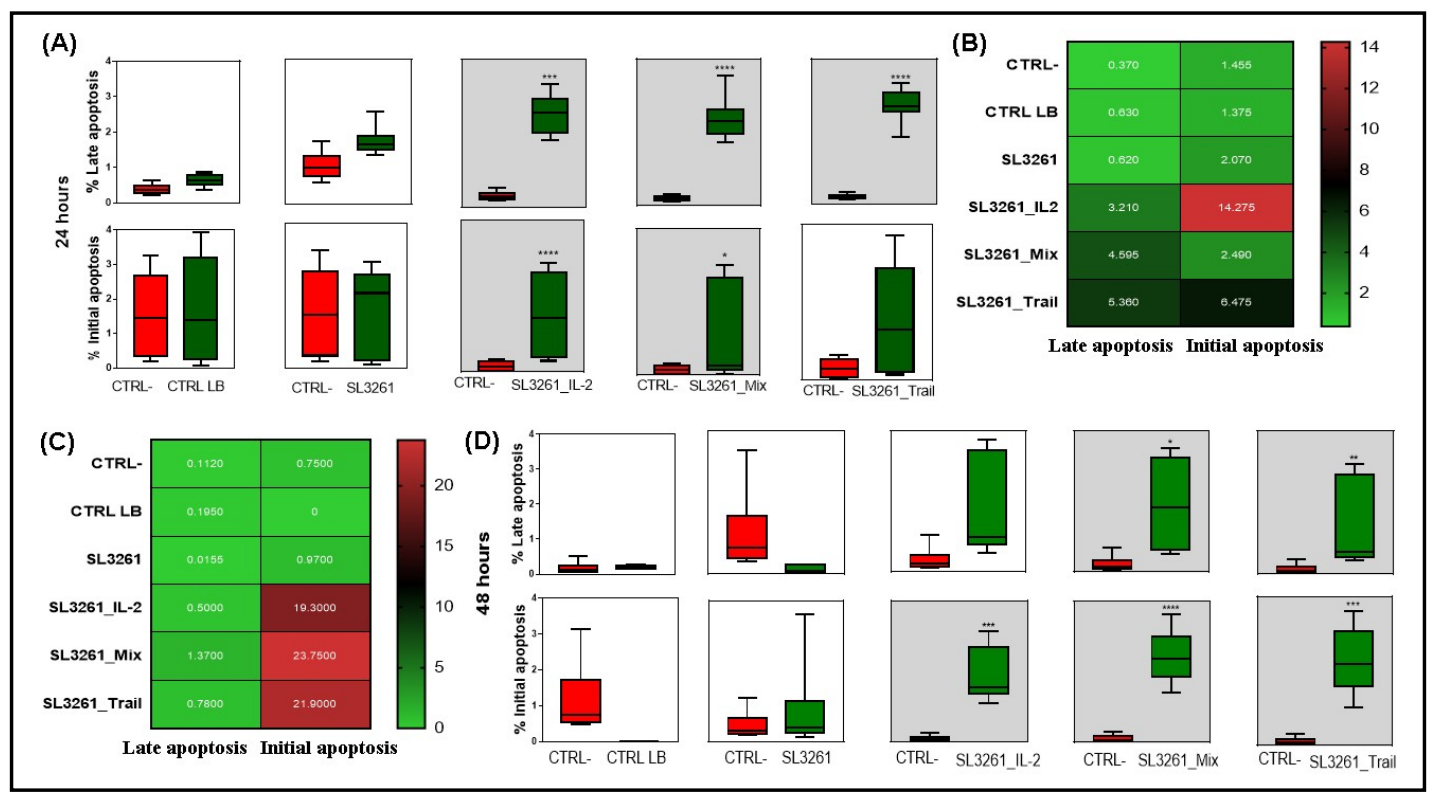

Fig. 8. Initial and late apoptosis in MB49 cells after 24 and 48 hours of exposure to IL-2, TRAIL and MIX proteins. Quantitative data analysis. (A, D) Cell analysis quantified in \% of initial and late apoptotic cells compared to the values quantified in the CTRL- group. Gray background represents significant difference. (B, C) Comparison between the average number of cells and correlation between initial and late apoptosis. Green represents low \% of initial and late apoptosis expression and red represents high \% of initial and late apoptosis expression. The assay was carried out at least in triplicate, in three independent experiments. Groups: CTRL-, no treatment; CTRL LB, DMEM + LB; SL3261, DMEM + SL3261; SL3261_IL-2, DMEM + SL3261-IL-2 plasmid; SL3261_TRAIL, DMEM and + SL3261-TRAIL plasmid; SL3261_MIX, DMEM + SL3261 - IL-2 + TRAIL plasmid. ( ${ }^{*}$ ) vs CTRL-; * $\mathrm{p}<0.05 ;{ }^{* *} \mathrm{p}<0.01$; ${ }^{* * *} \mathrm{p}<0.001$; ${ }^{* * * *} \mathrm{p}<0.0001$. The results were presented as the median with the upper and lower quartiles: Me [Q1; Q3]. 


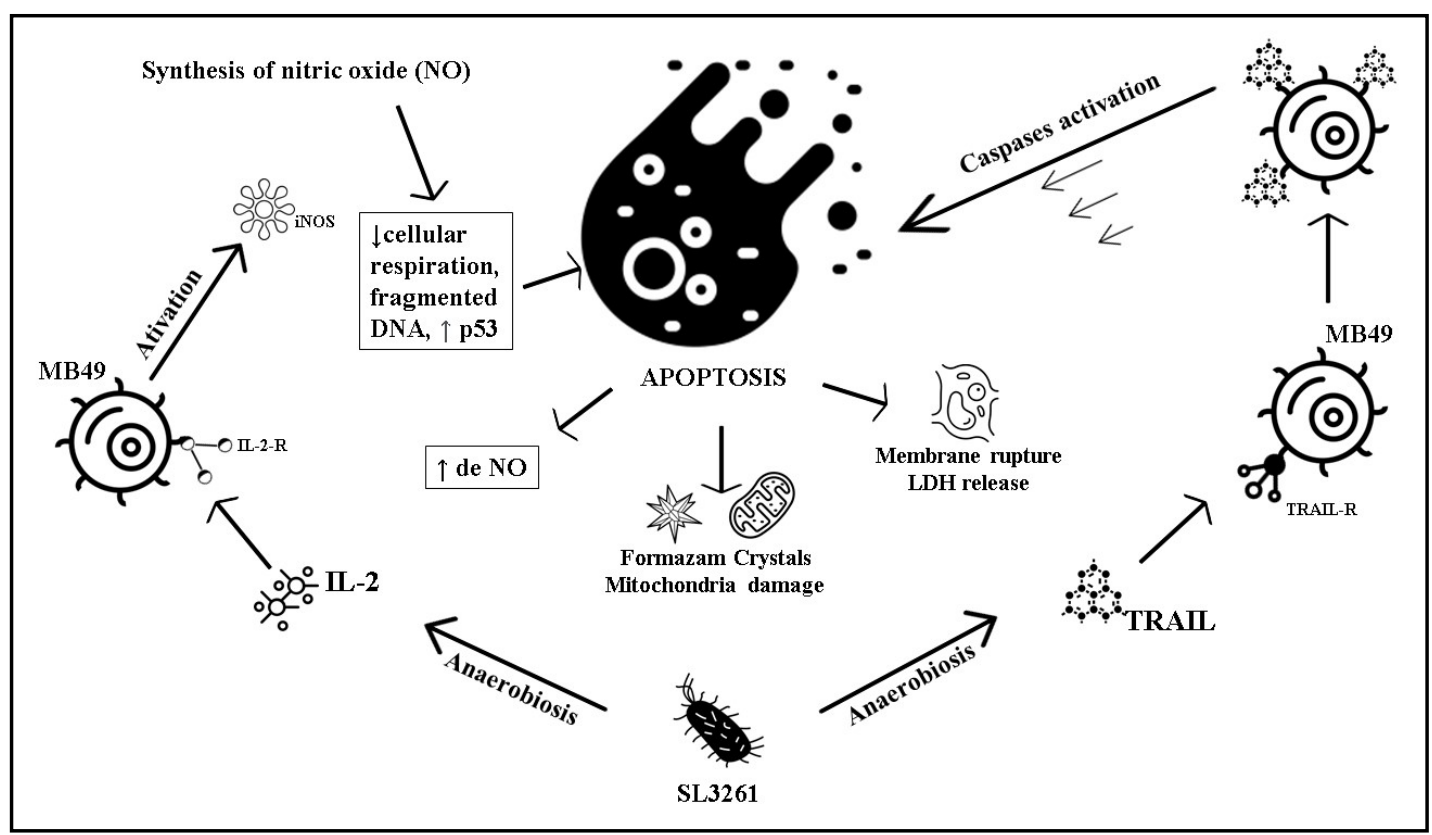

Fig. 9. Mechanisms triggered by the action of IL-2 and TRAIL proteins in the in vitro treatment of murine bladder tumor with MB49 cells. IL-2 and TRAIL bind to their receptors in the MB49 cell. IL-2 activates iNOS, which increases NO production generating cell damage and TRAIL activates caspases which leads to apoptosis.

A reduced and representative scheme of the IL-2 and TRAIL proteins action in the MB49 cells is shown in Fig. 9. The TRAIL protein finds its TRAIL-R receptor on the MB49 cell surface, which generates a signal for the cell to synthesize more TRAIL molecules. As a consequence of this signal amplification, caspase proteins are activated leading the cell to an apoptosis process, generating damage to the MB49 cell membrane and mitochondria, releasing LDH and reducing the formation of formazan crystals, thus damaging the cell. IL-2 also finds its IL-2-R receptor on the surface of the MB49 cell. Once that happens, the activation of the iNOS enzyme occurs, which leads to the production of NO. Consequently, there is a decrease in cellular respiration, DNA fragmentation, an increase in p53 transcription leading to MB49 in the apoptosis process, also causing damage to the MB49 cell membrane and mitochondria, releasing LDH and reducing the formation of formazan crystals.

\section{Discussion}

This study was designed to elucidate the antitumor effects of IL-2 and TRAIL proteins expressed by attenuated S. typhimurium (SL3261). The impact on apoptosis and oxidative stress pathways against MB49 murine bladder tumor cells at the times of 24 and 48 hours was analyzed. Bladder cancer is a highly malignant disease. Most of the available data are based on retrospective analyzes, and each risk factor for this type of disease must be seen in the light of genetic-environmental interactions to better assess its impact. Studies show, however, that the main cause of bladder cancer is the high prevalence of smoking and, in addition to the importance of primary prevention being emphasized, smoking cessation programs should be encouraged and supported, since the number of patients and related diseases, such as bladder cancer, is exorbitant [3], it is necessary to investigate new treatments, therapies and drugs to improve the bladder cancer world picture.

For this, studies using bladder tumor lines are promising. In order to explore and unveil the best interventions in bladder cancer, the MB49 cell line has been widely used, since it was developed from a tumor induced with the compound 7,12-dimethylbenz (a) anthracene 
(DMBA) in the bladder epithelium of male C57BL/ 6 mice. The induction model using the MB49 cell line for studies of bladder carcinoma is considered the most similar to human cancer, due to the markers of cell surface, immune profile and sensitivity to apoptosis [32].

The data obtained in this study show that there was a higher fluorescence emission by the 2 strains, SL3261_IL-2 and SL3261_TRAIL, confirming the heterologous expression of the IL-2 and TRAIL proteins. This approach is common in this type of construction in research with a tumor model, both with IL-2 [33] and TRAIL [34]. In addition, EmGFP protein and its derivatives did not cause apparent biological damage and did not require substrates or cofactors [35]. Another advantage of this type of construction is that the acquisition of fluorescence images, which is widely used in cancer gene therapy and in in vitro and in vivo studies, is completely non-invasive. Furthermore, there is no need to euthanize animals and it is easy to analyze by fluorescence microscopy or cytometry [36]. Both human and murine IL-2 cause cell proliferation of homologous species with high efficiency, that is, humans and mice have cross-reactivity [19]. The same can be said about TRAIL [34], showing that the chosen approach is relevant and grounded.

When analyzing the cell viability generated by a cytotoxic effect via the MTT assay of IL-2, TRAIL and the MIX of proteins in contact with the MB49 cell, it was noted that this effect occurred in the periods of 24 and 48 hours and with significant difference between treated groups and control groups, which can also be seen in optical microscopy images. There are numerous studies with tumor cells that have shown the cytotoxic action of the proposed therapy with TRAIL using the MTT technique, Including a study with 3 strains of human bladder cancer [37-40].

The marked action in decreasing cell viability in the groups treated with TRAIL and MIX is due to the strong induction of apoptosis mediated by TRAIL. One of the apoptosis activation pathways, the extrinsic death pathway, is initiated via apoptotic signal transduction cascades, mediated by members of the tumor necrosis factor receptor superfamily, which, when activated by their ligands such as TRAIL, quickly start activation of caspases resulting in apoptosis $[41,42]$.

In its turn, the intrinsic pathway is activated by intracellular signals from the mitochondria, is controlled by the pro and anti-apoptotic proteins of the Bcl2 family and has a substantial role in chemotherapy and radiation-induced cell death [42], which corroborates the data found in the present study by the analysis of damage in the mitochondria by the MTT method.

The marked action in decreasing cell viability was also observed in the group treated with IL-2. Studies have shown that IL-2 inhibited the growth of human ovarian cancer SKOV3 cells in vitro and in vivo, and also contributed to reducing the cell viability of liver cancer HepG2 cells in a study using a compound that was potentiated with IL-2 [43, 44]. Studies also suggest that several recombinants of human IL-2 may increase antitumor activity [45-48].

IL-2 activity in vitro can be partially mediated via NO, which has anti-angiogenic and anti-tumor properties [49]. NO is produced in large quantities from the amino acid L-arginine by the enzyme iNOS. Excessive uncontrolled production of NO can result in damage to the host cell due to its high reactive potential [50]. In the case of TRAIL, the presence of NO was observed, which may have caused cell death due to apoptosis. The high production of NO in the groups treated with IL-2 and MIX, may occur due to the presence of IL-2R (IL-2 receptor) in tumor cells [51] and the binding with recombinant IL-2 led to the activation of iNOS (NO synthase isoform II), typically present in this cell type [52]. Activation may be due to the response to stimuli such as ultraviolet radiation, ozone, trauma, bacterial products, in addition to cytokines and other inflammatory mediators [53]. This activation suppresses cell respiration and DNA synthesis, causes DNA fragmentation, has an effect on pro-apoptotic modulation (activation of caspase family proteases), increases the expression of p53 and alters the expression of proteins associated with apoptosis [54].

According to Peng, et al. [55] the ability of three types of bladder cancer, murine (MB49) and human (T24 and UMUC3) to recover and to form colonies has been demonstrated. The data from the present study showed that MB49 cells treated with IL-2, TRAIL and 
MIX proteins had a lower number of colony formation, that is, less recovery in 24 and 48 hours. As the treatments lead to the formation of apoptotic cells, they lose the capacity for cellular respiration and have DNA loss and fragmentation [54], causing their recovery to be compromised.

The levels of LDH secretion detected in the groups treated with TRAIL and MIX indicated that TRAIL induced apoptosis significantly. These results were also observed in lung cancer cells (lines A549, HCC-15) in which there was a greater release of LDH in the groups treated with TRAIL, showing that there was induction of apoptosis by this protein [56]. The same pattern was demonstrated in another study with 2 isoforms of TRAIL in the treatment against 3 human bladder cancer strains [57].

The images obtained by fluorescence and data from flow cytometry show that IL-2, TRAIL and MIX of proteins led MB49 cells to processes of cell death due to apoptosis, both in 24 and 48 hours. Among the nuclear markers and fluorescent dyes commonly used in the assays of verification and quantification of apoptosis by flow cytometry, the following stand out: propidium iodide, ethidium bromide, ethidium homodimer, 7-aminoactinomycin D (7AAD), acridine $[58,59]$.

A study with gastric cancer cells (strains MGC803 and SGC7901) demonstrated by flow cytometry, using the PE Annexina V marker, that TRAIL induced cell death by apoptosis in 48 hours of experiment [57]. The same has been demonstrated in prostate cancer cells [60].

IL-2 has apoptotic effects demonstrated due to its induction of NO production, as shown in our study. This can act as a pro-apoptotic modulator, activating proteases of the caspase family through the release of mitochondrial cytochrome $\mathrm{C}$ in the cytosol, increased expression of p53 and changes in the expression of proteins associated with apoptosis including the Bcl-2 family [61]. This type of cell death occurs due to the reduction of cells, fragmentation of internucleosomal DNA, vacuoles in the membrane, and formation of small vesicles called apoptotic bodies $[62,63]$.

TRAIL induces apoptosis in tumor cells, however, there is a potential alternative to cell death represented by the ability of human and murine TRAIL receptors to induce necrosis, regardless of their apoptotic capabilities, when apoptosis induction fails or is actively inhibited. Consequently, the induction of necrosis programmed by TRAIL may represent a new and additional option, but still largely unexplored, for the elimination of tumor cells, in addition to the well-established strategies aimed at inducing apoptosis [64]. A cytotoxic action on tumor cells generating necrosis by IL-2, TRAIL and the protein mix could contribute to an even more effective treatment against cancer. It is worth mentioning that anti-tumor responses induced by Salmonella expressing IL-2 were correlated with decreased angiogenesis and increased necrosis within the tumor tissue [33]. This suggests that, like TRAIL, IL-2 can also activate necrosis pathways in tumor cells, which was demonstrated in our study, since treatment with both proteins resulted in late apoptosis. Thus, these findings can be correlated with the analyzed pathways, such as mitochondrial function, NO synthesis and damage to the cell membrane, showing that IL-2, TRAIL and MIX of proteins, synthesized by SL3261, lead to apoptosis of bladder tumor cells MB49.

\section{Conclusion}

When exposed to MB49 bladder tumor cells, the IL-2 and TRAIL proteins synthesized by attenuated S. typhimurium (SL3261), and through the analysis of various cell pathways, showed a cytotoxic effect that leads to a process of cell death by apoptosis. Both proteins have shown promising for treatment against bladder cancer, when administered together or separately. TRAIL and the MIX of proteins seemed to contribute slightly more, since the feat of TRAIL in the pathways of apoptosis showed greater action than IL-2. This suggests that the approach used in this study has therapeutic potential, since the use of bacterial strains and the target interleukins are already well elucidated, with studies in the clinical and commercial phase. The innovation proposed in this study consists in the use of IL-2 


\section{Cellular Physiology Cell Physiol Biochem 2021;55:460-476

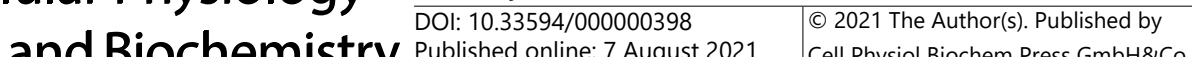 \\ Published online: 7 August 2021 Cell Physiol Biochem Press GmbH\&Co. KG \\ de Lima Fragelli et al.: IL-2 and TRIL Synthesized by Salmonella against Bladder Tumor Cells}

and TRAIL proteins, individually or in combination (MIX), expressed by the SL3261 strain developed, which might potentially serve as a live bacterial vector for a new therapy against bladder cancer.

\section{Acknowledgements}

The authors would like to thank Dr. Márcia Regina Cominetti (Departamento de Gerontologia, Universidade Federal de São Carlos, São Carlos, SP, Brazil) for the availability of equipment, to the technician Dr. Paulo Andrade (Departamento de Morfologia e Patologia, Universidade Federal de São Carlos - UFSCar) for helping to carry out the experiments and to Dr. Camila Tita Nogueira (Escola Paulista de Medicina, Universidade Federal de São Paulo - UNIFESP) for the help in English writing and review.

\section{Author Contributions}

Study development: Bruna, Luciana, Fernanda.

Study design: Bruna, Luciana, Adilson, Fernanda.

Data analysis: Bruna, Luciana, Joice, Krissia.

Preparation of the article: Bruna, Luciana, Joice, Krissia, Cynthia, Patricia.

Contribution of equipment and analysis: Adilson, Ricardo.

\section{Funding Sources}

This study was financed in part by the Coordenação de Aperfeiçoamento de Pessoal de Nível Superior - Brazil (CAPES) - Finance Code 001.

\section{Statement of Ethics}

The authors have no ethical conflicts to disclose.

\section{Disclosure Statement}

The authors have no conflicts of interest to declare.

\section{References}

1 Stewart PW, Wild CP(eds.): World Cancer Report 2014. WHO, IARC Publications. Geneva, Switzerland, 2014, pp 18-22.

2 World Health Organization (WHO): WHO report on cancer: setting priorities, investing wisely and providing care for all, 2020. URL: https://apps.who.int/iris/handle/10665/330745.

3 Burger M, Catto JWF, Dalbagni G, Grossman HB, Herr H, Karakiewicz P, Kassouf W, Kiemeney LA, La Vecchia C, Shariat S, Lotan Y: Epidemiology and risk factors of urothelial bladder cancer. Eur Urol 2013;63:234-241.

4 Sievert KD, Amend B, Nagele U, Schilling D, Bedke J, Horstmann M, Hennenlotter J, Kruck S, Stenzl A: Economic aspects of bladder cancer: What are the benefits and costs? World J Urol 2009;27:295-300.

5 Chorobik P, Marcinkiewicz J: Therapeutic vaccines based on genetically modified Salmonella: A novel strategy in cancer immunotherapy. Pol Arch Med Wewn 2011;121:461-467.

6 Coley WB: The treatment of malignant tumors by repeated inoculations of erysipelas: With a report of ten original cases. Am J Med Sci 1893;105:487-516.

7 Kramer MG, Masner M, Ferreira FA, Hoffman RM: Bacterial therapy of cancer: Promises, limitations, and insights for future directions. Front Microbiol 2018;9:1-9.

8 Chen F, Zang Z, Chen Z, Cui L, Chang Z, Ma A, Yin T, Liang R, Han Y, Wu Z, Zheng M, Liu C, Cai L: Nanophotosensitizer-engineered Salmonella bacteria with hypoxia targeting and photothermal-assisted mutual bioaccumulation for solid tumor therapy. Biomaterials 2019;214:119226. 


\section{Cellular Physiology Cell Physiol Biochem 2021;55:460-476 \begin{tabular}{l|l|l}
\hline DOI: 10.33594/000000398 & ( 2021 The Author(s). Published by
\end{tabular} and BIOChemistry Published online: 7 August $2021 \quad$ Cell Physiol Biochem Press GmbH\&Co. KG

9 Zheng JH, Min JJ: Targeted Cancer Therapy Using Engineered Salmonella typhimurium. Chonnam Med J 2016;52:173.

10 Pawelek JM, Low KB, Bermudes D: Bacteria as tumour-targeting vectors. Lancet Oncol 2003;4:548-556.

11 Felgner S, Frahm M, Kocijancic D, Rohde M, Eckweiler D, Bielecka A, Bueno E, Cava F, Abraham WR, Curtiss R, Häussler S, Erhardt M, Weiss S: Aroa-deficient Salmonella enterica serovar Typhimurium is more than a metabolically attenuated mutant. MBio 2016;7:1-12.

12 Hoiseth SK, Stocker BAD: Aromatic-dependent Salmonella typhimurium are non-virulent and effective as live vaccines. Nature 1981;238-239.

13 Ruby T, Mclaughlin L, Gopinath S, Monack D: Salmonella's long-term relationship with its host. FEMS Microbiol Rev 2012;36:600-615.

14 Dang LH, Bettegowda C, Huso DL, Kinzler KW, Vogelstein B: Combination bacteriolytic therapy for the treatment of experimental tumors. Proc Natl Acad Sci U S A 2001;98:15155-15160.

15 King I, Itterson M, Bermudes D: Tumor-targeted salmonella typhimurium overexpressing cytosine deaminase: A novel, tumor-selective therapy. Methods Mol Biol 2009;542:649-659.

16 Rosenberg SA: IL-2: The First Effective Immunotherapy for Human Cancer. J Immunol 2014;192:54515458.

17 Wiley SR, Schooley K, Smolak PJ, Din WS, Huang CP, Nicholl JK, Sutherland GR, Smith TD, Rauch C, Smith CA, Goodwin RG: Identification and characterization of a new member of the TNF family that induces apoptosis. Immunity 1995;3:673-682.

18 Mongkolsapaya J, Grimes JM, Chen N, Xu XN, Stuart DI, Jones EY, Screaton GR: Structure of the TRAIL-DR5 complex reveals mechanisms conferring specificity in apoptotic initiation. Nat Struct Biol 1999;6:10481053.

19 Mosmann TR, Coffman RL: Two types of mouse helper T-cell clone. Implications for immune regulation. Trends Immunol 1987;8:223-227.

20 Saltzman DA, Heise CP, Hasz DE, Zebede M, Kelly SM, Curtiss R, Leonard AS, Anderson PM: Attenuated Salmonella typhimurium containing interleukin-2 decreases MC-38 hepatic metastases: A novel anti-tumor agent. Cancer Biother Radiopharm 1996;11:145-153.

21 Zheng SJ, Wang P, Tsabary G, Chen YH: Critical roles of TRAIL in hepatic cell death and hepatic inflammation. J Clin Invest 2004;113:58-64.

22 Lawrence D, Shahrokh Z, Marsters S. Achilles K. Shih D, Mounho B, Ashkenazi A: Differential hepatocyte toxicity of recombinant Apo2L/TRAIL versions. Nat Med 2001;7:383-385.

23 Sambrook J, Russell DW: Molecular Cloning: A Laboratory Manual, ed 3. Cold Spring Harbor, New York, 2001.

24 Snapp E: Design and Use of Fluorescent Fusion Proteins in Cell Biology. Curr Protoc Cell Biol 2005;27:1-13.

25 Oxer MD, Bentley CM, Doyle JG, Peakman TC, Charles IG, Makoff AJ: High level heterologous expression in E.coli using the anaerobically-activated nirB promoter. Nucleic Acids Res 1991;19:2889-2892.

26 Ramos CRR, Abreu PAE, Nascimento ALTO, Ho PL: A high-copy T7 Escherichia coli expression vector for the production of recombinant proteins with a minimal N-terminal his-tagged fusion peptide. Brazilian J Med Biol Res 2004;37:1103-1109.

27 Mosmann T: Rapid Colorimetric Assay for Cellular Growth and Survival: Application to Proliferation and Cytotoxicity Assays. J Immunol Methods 1983;65:55-63.

28 Franken NAP, Rodermond HM, Stap J, Haveman J, van Bree C: Clonogenic assay of cells in vitro. Nat Protoc 2006;1:2315-2319.

29 Schindelin J, Arganda-Carreras I, Frise E, Kaynig V, Longair M, Pietzsch T, Preibisch S, Rueden C, Saalfeld S, Schmid B, Tinevez JY, White DJ, Hartenstein V, Eliceiri K, Tomancak P, Cardona A: Fiji: An open-source platform for biological-image analysis. Nat Methods 2012;9:676-682.

30 Saltzman BE: Colorimetric Microdetermination of Nitrogen Dioxide in the Atmosphere. Anal Chem 1954;26:1949-1955.

31 Green LC, Wagner DA, Glogowski J, Skipper PL, Wishnok JS, Tannenbaum SR: Analysis of nitrate, nitrite, and nitrate in biological fluids. Anal Biochem 1982;126:131-138.

32 Loskog A, Ninalga C, Hedlund T, Alimohammadi M, Malmström PU, Tötterman TH: Optimization of the MB49 mouse bladder cancer model for adenoviral gene therapy. Lab Anim 2005;39:384-393.

33 Barnett SJ, Soto LJ, Sorenson BS, Nelson BW, Leonard AS, Saltzman DA: Attenuated Salmonella typhimurium invades and decreases tumor burden in neuroblastoma. J Pediatr Surg 2005;40:993-998. 


\section{Cellular Physiology Cell Physiol Biochem 2021;55:460-476 \begin{tabular}{l|l|l}
\hline DOI: 10.33594/000000398 & (c)21 The Author(s). Published by
\end{tabular} and BIOChemistry Published online: 7 August $2021 \quad$ Cell Physiol Biochem Press GmbH\&Co. KG

34 Kim TH, Jo YG, Jiang HH, Lim SM, Youn YS, Lee S, Chen X, Byun Y, Lee KC: PEG-transferrin conjugated TRAIL (TNF-related apoptosis-inducing ligand) for therapeutic tumor targeting. J Control Release 2012;162:422428.

35 Zhao S, Maxwell S, Jimenez-Beristain A, Vives J, Kuehner E, Zhao J, O’Brien C, De Felipe C, Semina E, Li M: Generation of embryonic stem cells and transgenic mice expressing green fluorescence protein in midbrain dopaminergic neurons. Eur J Neurosci 2004;19:1133-1140.

36 Cronin M, Akin AR, Collins SA, Meganck J, Kim JB, Baban CK, Joyce SA, van Dam GM, Zhang N, van Sinderen D, O’Sullivan GC, Kasahara N, Gahan CG, Francis KP, Tangney M: High resolution in vivo bioluminescent imaging for the study of bacterial tumour targeting. PLoS One. 2012;7:e30940.

37 Cao HD, Yang YX, Lü L, Liu SN, Wang PL, Tao XH, Wang LJ, Xiang TX: Attenuated Salmonella typhimurium carrying TRAIL and VP3 genes inhibits the growth of gastric cancer cells in vitro and in vivo. Tumori 2010;96:296-303.

38 Xu S, Li D, Li T, Qiao L, Li K, Guo L, Liu Y: MiR-494 sensitizes gastric cancer cells to trail treatment through downregulation of survivin. Cell Physiol Biochem 2018;51:2212-2223.

39 Rasheduzzaman M, Jeong JK, Park SY: Resveratrol sensitizes lung cancer cell to TRAIL by p53 independent and suppression of Akt/NF-kB signaling. Life Sci 2018;208:208-220.

40 Qiu F, Hu M, Tang B, Liu X, Zhuang H, Yang J, Hua ZC: Annexin v-trail fusion protein is a more sensitive and potent apoptotic inducer for cancer therapy. Sci Rep 2013;3:1-9.

41 MacFarlane M: TRAIL-induced signalling and apoptosis. Toxicol Lett 2003;1393:89-97.

42 Johnstone RW, Frew AJ, Smyth MJ: The TRAIL apoptotic pathway in cancer onset, progression and therapy. Nat Rev Cancer 2008;8:782-798.

43 Ji K. Lin K. Wang Y. Du L. Xu C. He, N. Liu Q: TAZ inhibition promotes IL-2-induced apoptosis of hepatocellular carcinoma cells by activating the JNK/F-actin/mitochondrial fission pathway. Cancer Cell Int 2018;18:117.

44 Liu M, Wang H, Liu L, Wang B, Sun G: Melittin-MIL-2 fusion protein as a candidate for cancer immunotherapy. J Transl Med 2016;14:4-15.

45 Ju G, Collins L, Kaffka KL, Tsien WH, Chizzonite R, Crowl R, Bhatt R, Kilian PL: Structure-function analysis of human interleukin-2. Identification of amino acid residues required for biological activity. J Biol Chem 1987;262:5723-5731.

46 Rosenberg SA: Interleukin 2 for patients with renal cancer. Nat Clin Pract Oncol 2007;4:497.

47 Liu M, Wang B, Sun G, Qian D, Yan Z, Song X, Ding S: Expression, Purification, and Characterization of a Functional Mutant Recombinant Human Interleukin-2. Protein Pept Lett 2010;17:1280-1284.

48 Shanafelt AB, Lin Y, Shanafelt MC, Forte CP, Dubois-Stringfellow N, Carter C, Gibbons JA, Cheng SL, Delaria KA, Fleischer R, Greve JM, Gundel R, Harris K, Kelly R, Koh B, Li Y, Lantz L, Mak P, Neyer L, Plym MJ, et al.: A T-cell-selective interleukin 2 mutein exhibits potent antitumor activity and is well tolerated in vivo. Nat Biotechnol 2000;18:1197-1202.

49 Holzer P: Involvement of nitric oxide in the substance P-induced inhibition of intestinal peristalsis. Neuroreport 1997;8:2857-2860.

50 Lalsiamthara J, Senevirathne A, So MY, Lee JH: Safety implication of Salmonella based Brucella vaccine candidate in mice and in vitro human cell culture. Vaccine. 2018;36:1837-1845.

51 Murakami S: Soluble interleukin-2 receptor in cancer. Front Biosci 2004;9:3085-3090.

52 Pollock JS, Förstermann U, Tracey WR, Nakane M: Nitric oxide synthase isozymes antibodies. Histochem J 1995;27:738-744.

53 Förstermann U, Gath I, Schwarz P, Closs EI, Kleinert H: Commentary Isoforms of Nitric Oxide Synthase Distribution and Expressional. Biochem Pharmacol 1995;50:1321-1332.

54 Choudhari SK, Chaudhary M, Bagde S, Gadbail AR, Joshi V: Nitric oxide and cancer: a review. World J Surg Oncol 2013;11:1-11.

55 Peng M, Huang Y, Tao T, Peng CY, Su Q, Xu W, Darko KO, Tao X, Yang X: Metformin and gefitinib cooperate to inhibit bladder cancer growth via both AMPK and EGFR pathways joining at Akt and Erk. Sci Rep 2016;6:110 .

56 Zinnah KMA, Park SY: Duloxetine Enhances TRAIL-mediated Apoptosis via AMPK-mediated Inhibition of Autophagy Flux in Lung Cancer Cells. Anticancer Res 2019;39:6621-6633.

57 Szliszka E, Mazur B, Zdowicz G, Czuba ZP, Król W: TRAIL-induced apoptosis and expression of death receptor TRAIL-R1 and TRAIL-R2 in bladder cancer cells. Folia Histochem Cytobiol 2009;47:579-585. 


\section{Cellular Physiology Cell Physiol Biochem 2021;55:460-476 \begin{tabular}{ll|l|l|}
\hline DOI: 10.33594/000000398 & 2021 The Author(s). Published by
\end{tabular} and Biochemistry Published online: 7 August 2021 Cell Physiol Biochem Press GmbH\&Co. KG

58 Gatti R, Belletti S, Orlandini G, Bussolati O, Dall'Asta V, Gazzola GC: Comparison of annexin V and calcein-AM as early vital markers of apoptosis in adherent cells by confocal laser microscopy. J Histochem Cytochem 1998;46:895-900.

59 Lecoeur H, Gougeon ML: Comparative analysis of flow cytometric methods for apoptosis quantitation in murine thymocytes and human peripheral lymphocytes from controls and HIV-infected persons. Evidence for interference by granulocytes and erythrocytes. J Immunol Methods 1996;198:87-99.

60 Szliszka E, Krol W: Soy isoflavones augment the effect of TRAIL-mediated apoptotic death in prostate cancer cells. Oncol Rep 2011;26:533-541.

61 Chaudhary SC, Singh T, Kapur P, Weng Z, Arumugam A, Elmets CA, Kopelovich L, Athar M: Nitric oxidereleasing sulindac is a novel skin cancer chemopreventive agent for UVB-induced photocarcinogenesis. Toxicol Appl Pharmacol 2013;268:249-255.

62 Mohammadinejad R, Moosavi MA, Tavakol S, Vardar DÖ, Hosseini A, Rahmati M, Dini L, Hussain S, Mandegary A, Klionsky DJ: Necrotic, apoptotic and autophagic cell fates triggered by nanoparticles. Autophagy 2019;15:4-33.

63 Elmore S: Apoptosis: A Review of Programmed Cell Death. Toxicol Pathol 2007;35:495-516.

64 Voigt S, Philipp S, Davarnia P, Winoto-Morbach S, Röder C, Arenz C, Trauzold A, Kabelitz D, Schütze S, Kalthoff H, Adam D: TRAIL-induced programmed necrosis as a novel approach to eliminate tumor cells. BMC Cancer 2014;14:74. 